\title{
Nutrient transfer from soil to surface waters \\ Differences between nitrate and phosphate
}

\author{
Journal Article \\ Author(s): \\ Gächter, René; Steingruber, Sandra M.; Reinhardt, Miriam; Wehrli, Bernhard \\ Publication date: \\ 2004-03 \\ Permanent link: \\ https://doi.org/10.3929/ethz-b-000051422 \\ Rights / license: \\ In Copyright - Non-Commercial Use Permitted \\ Originally published in: \\ Aquatic Sciences 66(1), https://doi.org/10.1007/s00027-003-0661-x
}




\title{
Research Article
}

\section{Nutrient transfer from soil to surface waters: Differences between nitrate and phosphate}

\author{
René Gächter ${ }^{1, *}$, Sandra M. Steingruber ${ }^{2}$, Miriam Reinhardt ${ }^{1}$ and Bernhard Wehrli $^{1}$ \\ 1 Swiss Federal Institute for Environmental Science and Technology (EAWAG), Limnological Research Center, \\ CH-6047 Kastanienbaum, Switzerland \\ ${ }^{2}$ Dipartimento del territorio, Divisione dell'ambiente, Sezione della protezione dell'aria, dell'acqua e del suolo, \\ Ufficio della protezione e della depurazione delle acque, via C. Salvioni 2a, CH-6500 Bellinzona, Switzerland
}

Received: 29 March 2003; revised manuscript accepted: 18 September 2003

\begin{abstract}
Nitrate $\left(\mathrm{NO}_{3}^{-}\right)$and soluble reactive phosphorus (SRP), the two major dissolved $\mathrm{N}$ and $\mathrm{P}$ species available to aquatic biota, respond differently to varying water discharge rates (Q) in agricultural drainage pipes and rivers (Fig. 1): SRP concentrations are positively related to $\mathrm{Q}$, whereas $\mathrm{NO}_{3}^{-}$concentrations decrease with increasing discharge rates. In addition, $\mathrm{NO}_{3}-\mathrm{N}$ concentrations exceed (in mass units) SRP concentrations up to 700-fold even though the liquid manure applied to agricultural fields has a N:P ratio equal to only about 5 . Preferential flow of rainwater across the soil column and different affinities of the two nutrients for the soil matrix explain these differences in behaviour and mobility:
\end{abstract}

i. Concentrations of substances that have a high sorption affinity for the soil matrix (such as SRP) tend to increase in drainage pipes and streams as water discharge increases.

ii. Concentrations of species that are not retarded by sorption processes (such as $\mathrm{NO}_{3}^{-}$) and, hence, do not accumulate in the topsoil, tend to be negatively related to discharge rate.

Differences in the availability and pool size of $\mathrm{NO}_{3}^{-}$and SRP in the topsoil explain the different hysteresis patterns if $\mathrm{NO}_{3}^{-}$ and SRP concentrations are plotted versus the corresponding discharge rate during precipitation events (Fig. 2).

Key words. Phosphorus; nitrogen; drainage; agriculture; eutrophication.

\section{Introduction}

Nitrogen $(\mathrm{N})$ and phosphorus $(\mathrm{P})$ are the two major nutrients controlling productivity of freshwater ecosystems (Elser et al., 1990). Due to advanced wastewater treatment and the banning of polyphosphates in detergents, soluble reactive phosphorus (SRP) concentrations have decreased substantially in most surface waters in central Europe during the past decades (Gächter and Wehrli, 1998; Zimmermann, 1999). Today, fertilized soils are the most important source of the remaining P load (Foy and

* Corresponding author phone: +41 4134013 41;

e-mail: rene.gaechter@eawag.ch

Published on Web: March 24, 2004
Withers,1995; Stadelmann et al., 2002) and, in many cases, prevent complete restoration of eutrophic lakes.

Contrary to $\mathrm{P}, \mathrm{NO}_{3}^{-}$concentrations are still increasing or remain at elevated concentrations in Swiss surface waters (Zobrist et al., 1990). Intensified application of $\mathrm{N}$ fertilizer, increasing atmospheric $\mathrm{N}$ deposition (originating from combustion processes), and lower denitrification in less productive lakes (due to decreased P load) (Höhener and Gächter, 1993; Mengis et al., 1997; Steingruber, 2001) and rivers less polluted with organic wastes may have contributed to this development.

In many groundwater wells, $\mathrm{NO}_{3}^{-}$concentrations temporarily exceed the drinking water limit of $40 \mathrm{mg} \mathrm{NO}_{3}^{-} \mathrm{L}^{-1}$ (EEA, 1998; Zobrist et al., 1990) and elevated $\mathrm{N}$ loading contributes to eutrophication of marine coastal areas 
(Nixon et al., 1996; Tyrrell, 1999). Furthermore, $\mathrm{NO}_{2}^{-}$ $\left(>0.02 \mathrm{mg} \mathrm{NO}_{2}^{-}-\mathrm{N}\right.$ liter $\left.{ }^{-1}\right)$ and $\mathrm{NH}_{3}(>0.02 \mathrm{mg} \mathrm{NH}-\mathrm{N}$ liter $^{-1}$ ) are toxic to fish (Müller, 1990) and out-gassing $\mathrm{N}_{2} \mathrm{O}$, an intermediate product of nitrification and denitrification, contributes to the global warming and the decomposition of the ozone layer. For these reasons the European Countries participating in the Rhine Action Plan agreed to decrease the $\mathrm{N}$ discharge into the Rhine River by $50 \%$ (BUWAL, 1993). In agrarian regions of Switzerland with mainly arable land and grassland, approximately 50 to $60 \%$ of the aquatic $\mathrm{N}$ (2000 to $4000 \mathrm{~kg} \mathrm{~km}^{-1}$ $\mathrm{yr}^{-1}$ ) originates from agricultural soils, $20 \%$ from wastewater treatment plants, $20 \%$ from natural sources and $5 \%$ from combustion processes.

Since soils are important sources for aquatic N and $\mathrm{P}$, and both nutrients are of concern for freshwater as well as marine ecosystems, this study examines three agricultural drainage systems as examples of the soil/water boundary and compares results with those obtained from intensive river monitoring (Gächter et al., 1996). It further relates concentrations of $\mathrm{NO}_{3}^{-}$and SRP to water discharge rates $(\mathrm{Q})$ and explains differences in behavior and mobility of the two nutrient species by their different sorption affinity to the soil matrix.

\section{Study sites and methods}

\section{Sites}

The three investigated drainage systems discharge into the Buchser Weiher, the Boden Weiher and into the river Kleine Aa in Sempach (Table 1) and are located in the Central Swiss Plateau. They drain mainly grassland and some cropland (cereals, rape, corn) and the average annual precipitation at all sites equals about $1200 \mathrm{~mm}$ year $^{-1}$

The river Kleine Aa drains a sub-catchment $\left(6.9 \mathrm{~km}^{2}\right)$ at the northeastern end of Lake Sempach, situated at an elevation between 505 and $670 \mathrm{~m}$, with $87 \%\left(5.4 \mathrm{~km}^{2}\right)$ of the watershed used as farmland. Most of the area is cultivated as grassland, where intensive dairy farming and pig production prevail (average livestock density is 3.1 dairy-cow equivalents $\mathrm{ha}^{-1}$ ). The grassland is mowed up to seven times during the growing season and liquid manure is applied frequently after each cut (Gächter et al., 1998).

\section{Sampling and chemical analysis}

At the Buchser Weiher site, the water discharge of the drainage pipe was monitored with a calibrated triangular weir ("V" angle $90^{\circ}$, height $21 \mathrm{~cm}$ ) combined with a limnigraph (instrument recording the water level behind the weir). Forty-one spot samples were collected at about bi-weekly intervals and at a higher sampling frequency during two rainy periods in May 1999.

At the Boden Weiher and Sempach sites, drainage water discharge was measured electronically with a magnetic inductive flow meter (PROline promag 50/53 W). Spot samples were collected every second day at the Boden Weiher site and at a frequency of 0.3 to $1 \mathrm{~h}^{-1}$ at the Sempach site.

Water discharge of the river Kleine Aa was monitored at a calibrated station equipped with a limnigraph. At this site $\mathrm{NO}_{3}^{-}$and SRP concentrations were determined online (every $35 \mathrm{~min}$ ) with a Flow Injection Analyzer (FIA) as described by Gächter et al., (1996).

Standard methods were applied for SRP (molybdate method: DEV, 1996) and $\mathrm{NO}_{3}^{-}$(salicylic acid method: DEV, 1996) analyses. At the site Buchser Weiher, $\mathrm{NO}_{3}^{-}$ was measured as $\mathrm{NO}_{2}^{-}$with a Procon Auto Analyser after reduction of $\mathrm{NO}_{3}^{-}$to $\mathrm{NO}_{2}^{-}$on a cadmium column (DEV, 1996) from May to June 1999.

\section{Results and discussion}

At all sites, $\mathrm{N}$ and $\mathrm{P}$ had been applied to the grassland soil as liquid manure at an annual rate of about $233 \mathrm{~kg} \mathrm{~N} \mathrm{ha}^{-1}$ $\mathrm{yr}^{-1}$ and $47 \mathrm{~kg} \mathrm{P} \mathrm{ha}^{-1} \mathrm{yr}^{-1}$ (Gächter et al., 1996). Precipitation and microbiological $\mathrm{N}$ fixation probably add about $30 \mathrm{~kg} \mathrm{~N} \mathrm{ha}^{-1} \mathrm{yr}^{-1}$ and $1 \mathrm{~kg} \mathrm{P}$ ha $\mathrm{yr}^{-1}$ (Krummenacher

Table 1. Location and brief description of investigated systems.

\begin{tabular}{lllllll}
\hline Name & Type & $\begin{array}{l}\text { Sampling } \\
\text { location* }\end{array}$ & Crop characterization & $\begin{array}{l}\text { Drainage } \\
\text { area } \mathrm{m}^{2}\end{array}$ & Investigation period & References \\
\hline Buchser Weiher & drainage pipe & $644250 / 228300$ & $\begin{array}{l}\text { 63\% grass, 33\% crop, } \\
4 \% \text { forest }\end{array}$ & $6 \cdot 10^{4}$ & Feb 1998 to June 1999 & Steingruber 2001 \\
Boden Weiher & drainage pipe & $659600 / 218000$ & $\begin{array}{l}\text { grassland } \\
\text { cropland }\end{array}$ & $1 \cdot 10^{3}$ & Feb 2002 to Dec 2002 & this study \\
Sempach & drainage pipe & $657220 / 219900$ & $4 \cdot 10^{4}$ & May 1994 to June 1994 this study \\
Kleine Aa & river & $657250 / 219800$ & mainly grassland & $7 \cdot 10^{6}$ & May 1993 to Mar 1994 Gächter et al. 1996, \\
\hline
\end{tabular}

* Swiss mapping system coordinates. 
1976) and $65 \mathrm{~kg} \mathrm{~N} \mathrm{ha}^{-1} \mathrm{yr}^{-1}$ (Gächter et al., 1996), respectively, resulting in total deposition rates of $328 \mathrm{~kg} \mathrm{~N}$ $\mathrm{ha}^{-1} \mathrm{yr}^{-1}$ and $48 \mathrm{~kg} \mathrm{P} \mathrm{ha} \mathrm{yr}^{-1}$. Most of this supply is taken up by the crop and harvested $\left(200 \mathrm{~kg} \mathrm{~N} \mathrm{ha}^{-1} \mathrm{yr}^{-1}\right.$ and $30 \mathrm{~kg} \mathrm{P} \mathrm{ha}^{-1} \mathrm{yr}^{-1}$ ). The surplus either accumulates in the soil, is lost to groundwater and surface waters or escapes to the atmosphere as $\mathrm{NH}_{3}, \mathrm{~N}_{2} \mathrm{O}$ and/or $\mathrm{N}_{2}$.

$\mathrm{NO}_{3}^{-}$and SRP concentrations responded consistently different at each site when drainage water discharge rates varied (Fig. 1). SRP concentrations were positively related to water discharge, whereas $\mathrm{NO}_{3}^{-}$concentrations decreased with increasing discharge rates. Nevertheless, average $\mathrm{NO}_{3}^{-}$concentrations (in mass units) exceeded average SRP concentrations (in mass units) 27-fold and 680-fold at the Boden Weiher and the Buchser Weiher sites, respectively (At the site Sempach, $\mathrm{NO}_{3}^{-}$was not measured). Since in the supplied liquid manure the N:P ratio equals only about 5 (Gächter et al., 1996), the strongly elevated ratio in the drainage water indicates that the combined soil/crop system retains P much more efficiently than N. Reported annual loss rates to the surface water account for up to $20 \%$ and $3 \%$ of the deposited $\mathrm{N}$ and $\mathrm{P}$ fertilizer, respectively (Gächter et al., 1996).

In addition to the dependence on water discharge, Figure 1 indicates lower $\mathrm{NO}_{3}^{-}$and SRP concentrations during winter than during summer at equal water discharge rates in the river Kleine Aa. The sampled drainage pipes Boden Weiher and Buchser Weiher revealed much lower seasonal variability. This observation suggests that the seasonal differences observed in the river Kleine Aa were not only due to the absence of manure application to the soil in winter but also to a higher ground-water: drainage-water ratio during the typically drier winter months. An increase of this ratio causes the SRP concentration of the river water to decrease because of the usually lower SRP concentration in the groundwater rather than in the drainage water. Furthermore, during winter, the missing $\mathrm{NH}_{4}^{+}$application to the soil in combination with reduced nitrification rates explain the somewhat lower $\mathrm{NO}_{3}^{-}$concentrations in the groundwater dominated river.

Due to the prohibition of spreading liquid manure from November 1 to the end of February, farms with a small storage capacity are forced to empty partly their tanks just prior to or at the end of this period. Due to low temperature and irradiation, however the ability of plants to take up these nutrients is very limited. Thus, it seems logical that in two drainage pipes as well as in the river Kleine Aa the highest SRP concentrations (apparent high value outliners in Fig. 1) were observed just after the beginning and the very end of the mentioned period.

In the initial phase of rain events, SRP concentrations in the Kleine Aa remained consistently low until the discharge had passed its maximum. Then they quickly increased to maximum values and slowly decreased again approximately in proportion to the decreasing water dis- charge rate (Fig. 2). In addition to the mentioned seasonally variable ground-water: drainage-water ratio, this short-term hysteresis also contributes considerably to the observed scatter of data if SRP or $\mathrm{NO}_{3}^{-}$concentrations are plotted versus water discharge rates (Fig. 1).

As shown by Gächter et al. (1998), in relatively impermeable soils that developed from glacial till (Würm glaciation) and Molasse, about equal fractions (35\%) of the annual precipitation trickle slowly through the biogeochemically active soil matrix or bypass it quickly along macropores. During dry weather periods, drainage pipes and the river collect only groundwater. During rain, part of the discharge (the interflow) is generated in the topsoil and conducted quickly to the drainage pipes or river with little further chemical alteration. If the qualities of the groundwater and the interflow generated in the topsoil differ, the resulting river water quality depends on the concentration and quantity of both sources and, hence, on total discharge.

The high affinity of SRP for the soil matrix is well established (e.g., Scheffer et al., 1992). Most of the SRP applied to the soil accumulates in the topsoil and little reaches the groundwater as the water slowly trickles through the soil matrix. Since this abiotic SRP sorption is reversible, desorption sustains elevated SRP concentrations in the topsoil pore water as long as the rate of desorption equals or exceeds the flushing or dilution rate of the soil porewater by rainwater. As Gächter et al. (1998) and Stamm et al. (1998) have demonstrated, vertical macropores bypassing the soil matrix can drain this SRP enriched interflow from the topsoil layer to the aquifer or drainage pipes within minutes to hours. Hence, during rainy weather, drainage water represents a variable mixture of "old" groundwater and interflow. Since desorption velocity of SRP from the soil matrix to the aqueous phase is limited, the SRP concentration of the interflow depends on the residence time of the water in the topsoil. It remains relatively low on the rising limb of the hydrograph when the flushing rate of the soil pores is large and, hence, the residence time of the rainwater in the topsoil is short. However, as soon as precipitation and, accordingly, continuous dilution of topsoil pore-water stops, the SRP concentration of the interflow increases. As a consequence, SRP concentration in the river water suddenly increases when the drainage water discharge begins to decrease and it gradually decreases about in proportion to the total flow rate as the drainage and interflow discharge decreases and groundwater flow becomes gradually more important (Fig. 2). Spot sampling at a low frequency would not reveal this hysteresis behaviour but result in an unexplained large random scattering if SRP concentrations were plotted versus the corresponding discharge rate (Fig. 1).

In contrast to $\mathrm{SRP}, \mathrm{NO}_{3}^{-}$is not retained in the solid soil matrix. Pores contribute only about $50 \%$ to the topsoil 

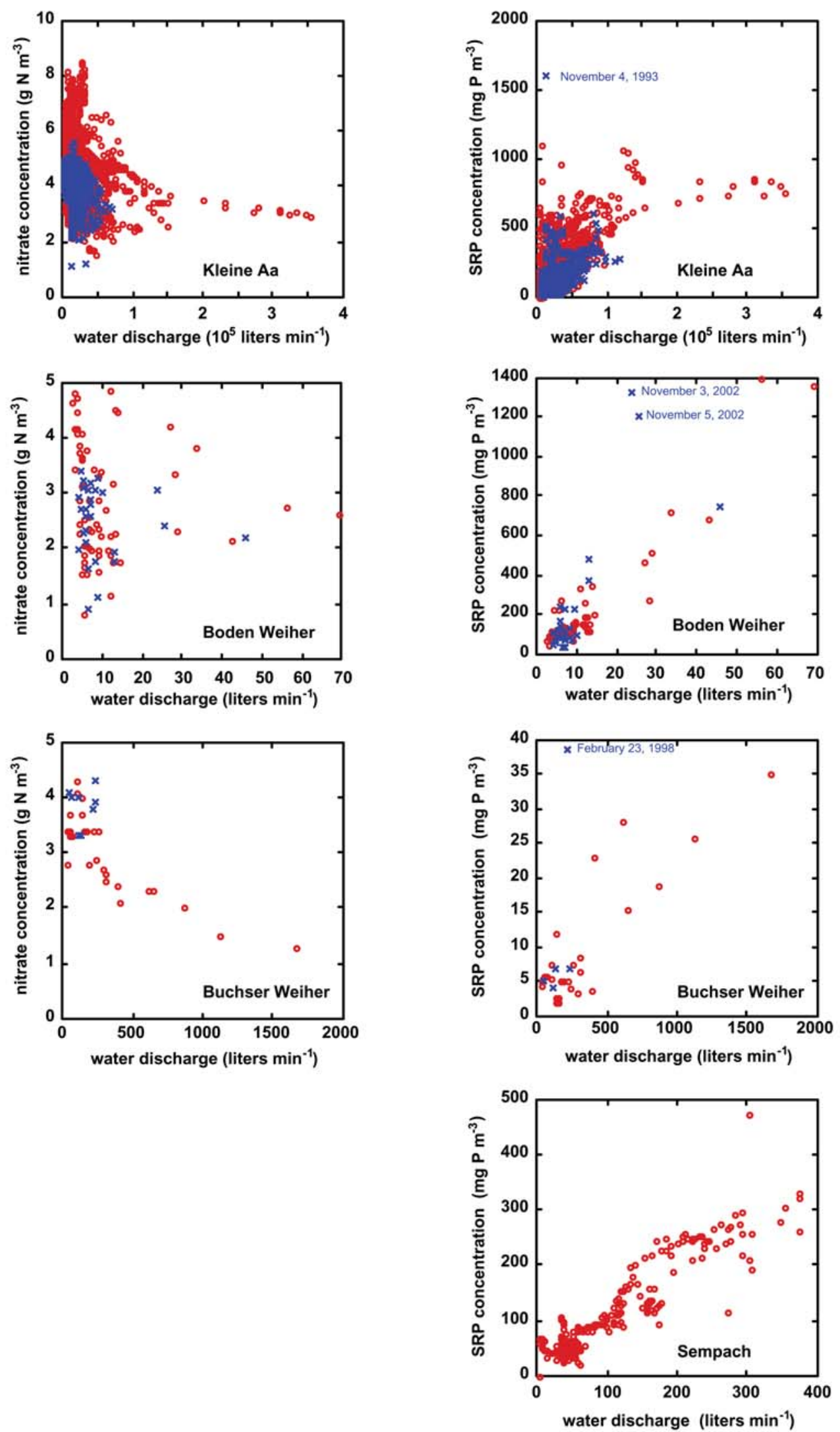

Figure 1. $\mathrm{NO}_{3}^{-}$and SRP concentrations as a function of discharge rates in three drainage pipe effluents and in the river Kleine Aa. (In the effluent of the drainage pipe "Sempach" $\mathrm{NO}_{3}^{-}$was not measured). Red circles represent data obtained from March 1 to October 31. Blue crosses represent data obtained from November 1 to February 28. 

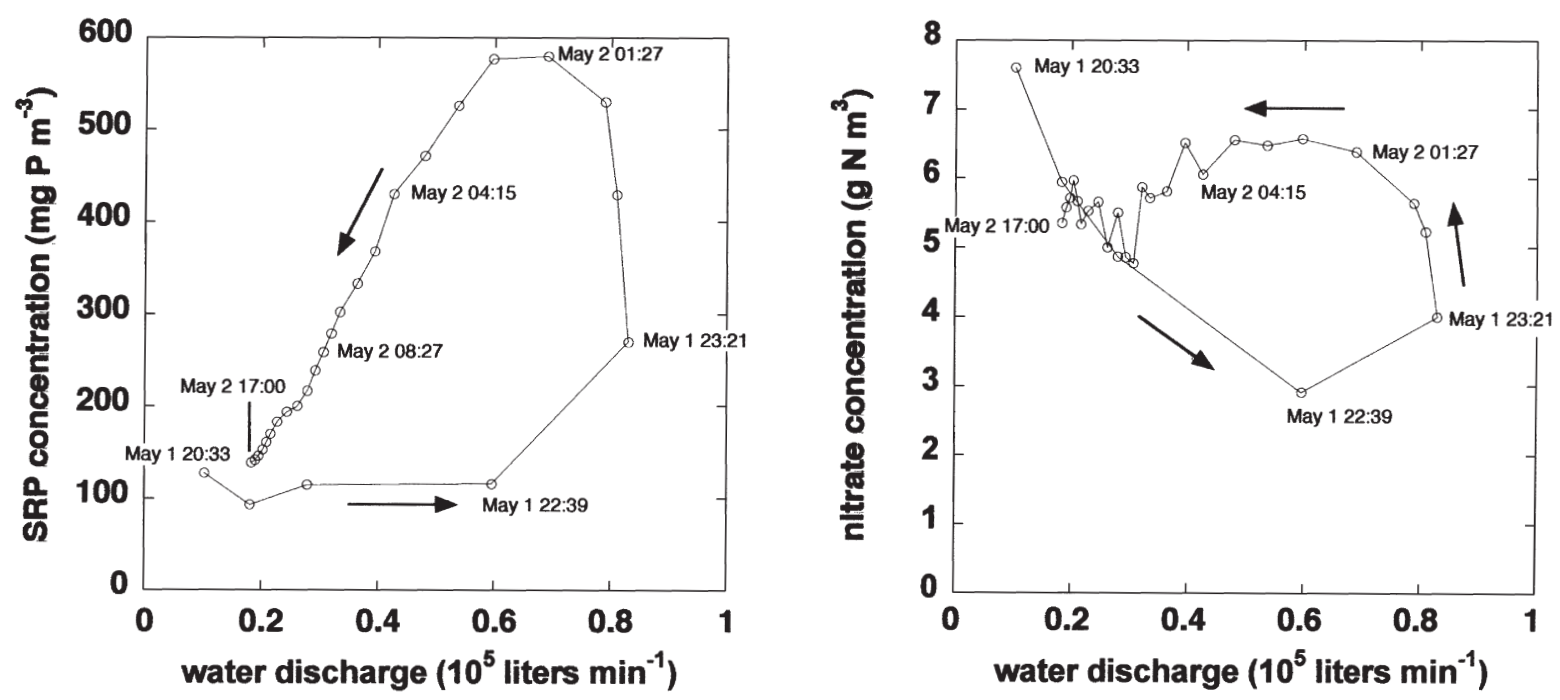

Figure 2. Examples of $\mathrm{SRP} / \mathrm{Q}$ and $\mathrm{NO}_{3}^{-} / \mathrm{Q}$ hysteresis during a rainy period (May 11993 20:33 to May 2 1993 17:00) in the river Kleine Aa.

bulk volume and, in general, are not water saturated. Thus, the topsoil cannot sustain elevated $\mathrm{NO}_{3}^{-}$concentration when its pores are flushed with rainwater low in $\mathrm{NO}_{3}^{-}$. Typical rainwater concentrations $(0.3 \mathrm{mg} \mathrm{NO}-\mathrm{N}$ $\mathrm{L}^{-1}$ ) are about ten times lower than typical groundwater concentrations ( 3 to $5 \mathrm{mg} \mathrm{NO}_{3}^{-}-\mathrm{N} \mathrm{L}^{-1}$ ). Therefore, as long as macropores drain topsoil-generated interflow, $\mathrm{NO}_{3}^{-}$ concentrations will be more or less inversely related to the total discharge of drainage pipes or rivers. However, as shown in Figure 2, $\mathrm{NO}_{3}^{-}$concentrations recover after the interflow ceases and groundwater flow starts to dominate the total discharge again. Therefore, the relationship between $\mathrm{NO}_{3}^{-}$concentration and discharge is also a hysteresis, but with a different pattern than the SRP hysteresis.

It is probable that $\mathrm{NO}_{3}^{-}$concentrations as well as the mobility of SRP are highly variable in the topsoil, depending on the timing of the last manure application, the intensity of biogeochemical reactions (e.g., nitrification), and the recent nutrient uptake by crop plants. This variability also affects the quality of the water supplied to the aquifer, which is further modified by the pathways the water selects across the soil column. These pathways can include matrix flow accompanied by SRP sorption to the soil matrix in deeper layers and microbial production (nitrification) or consumption (denitrification) of $\mathrm{NO}_{3}^{-}$, or fast flow along preferential flow paths that are biogeochemically nearly inert. This explains why $\mathrm{NO}_{3}^{-}$and SRP concentrations are highly variable in the topsoil water as well as in the groundwater and, consequently, in any mixture of the two components (Fig. 1).

In summary, macropores draining pore water from the topsoil to drainage pipes or rivers affect their water quality, depending on the physical-chemical properties of the considered substance. Substances that are retarded by sorption (e.g., SRP) tend to be positively related to the discharge rate as long as the soil matrix is not yet completely saturated from the topsoil down to the aquifer. However, limited desorption velocity from the soil matrix causes hysteresis, with lower SRP concentrations occurring on the rising limb of the hydrograph. The resulting large scattering partly masks the postulated positive $[\mathrm{P}] / \mathrm{Q}$ relationship. In contrast, substances that are not retarded by sorption processes (e.g., $\mathrm{NO}_{3}^{-}$) and, hence, do not accumulate in the topsoil tend to be negatively related to the discharge rate.

\section{Acknowledgment}

Dan McGinnis, Joseph S. Meyer, Beat Müller, Karen Umbach and Jürg Zobrist read and amended the manuscript. The constructive comments of an anonymous referee to an earlier version of the manuscript are acknowledged.

\section{References}

Bundesamt für Umwelt, Wald und Landschaft (BUWAL) Bern. 1993. Der Stickstoffhaushalt in der Schweiz. Konsequenzen für Gewässerschutz und Umweltentwicklung, Schriftenreihe Umwelt 209: 1-74.

Deutsche Einheitsverfahren zur Wasseruntersuchung (DEV) 1996. Band 2, Weikheim

Elser, J. J., E. R. Marzolof and C. R. Goldman, 1990. Phosphorus and nitrogen limitation of phytoplankton in the freshwaters of North America: A review and critique of experimental enrichments. Can. J. Fish. Aquat. Sci. 47: 1468-1477.

European Environment Agency (EEA), 1998. Groundwater Quality and Quantity. Copenhagen, Denmark. p. 35-39. 
Foy, R. H. and P. J. A. Withers, 1995. The contribution of agricultural phosphorus to eutrophication. Proc. Fert. Soc. 365: 32.

Gächter, R. and B. Wehrli, 1998. Ten years of artificial mixing and oxygenation: No effect on the internal P loading of two lakes. Environ. Sci. Technol. 32: 3659-3665.

Gächter, R., A. Mares, C. Stamm, U. Kunze and J. Blum, 1996. Dünger düngt Sempachersee. Agrarforschung 3: 329-332.

Gächter, R., J. M. Ngatiah and C. Stamm, 1998. Transport of phosphate from soil to surface waters by preferential flow. Environ. Sci. Technol. 32: 1865-1869.

Höhener, P. and R. Gächter, 1994. Nitrogen cycling across the sediment-water interface in a eutrophic, artificially oxygenated lake. Aquat. Sci. 56: 115-132.

Krummenacher, T., 1976. Die Nährstoffbilanz des Alpnachersees. Ph. D. Thesis No. 5689, Eidgenössische Technische Hochschule (ETH), Zurich.

Mengis M., R. Gächter, B. Wehrli and S. Bernasconi, 1997. Nitrogen elimination in two eutrophic lakes. Limnol. Oceanogr. 42:1530-1543.

Müller, R., 1990. Stickstoff-Toxizität für Fische und herzuleitende Grenzwerte. EAWAG-News 30: 33-36.

Nixon, S. W., J. W. Ammerman, L. P. Atkinson, V. M. Berounsky, G. Billen, W. C. Boicourt, W. R. Boynton, T. M. Church, D. M. Di Toro, R. Elmgren, J. H. Garber, A. E. Giblin, R. A. Jahnke, N.
J. P. Owens, M. E. Q. Pilson and S. P. Seitzinger, 1996. The fate of nitrogen and phosphorus at the land sea margin of the North Atlantic Ocean. Biogeochemistry 35: 141-180.

Scheffer, F., P. Schachtschabel, H.-P. Blume, G. Brümmer, K.-H. Hartge, U. Schwertmann, W. R. Fischer, M. Renger and O. Strebel, 1992. Lehrbuch der Bodenkunde. Enke, Stuttgart. 491 pp.

Stadelmann, P., R. Lovas and E. Butscher, 2002. 20 Jahre Sanierung und Überwachung des Baldeggersees. Mittg. Natw. Ges. Luzern 37: 115-164.

Stamm, C., H. Flühler, R. Gächter and J. Leuenberger, 1998. Preferential Transport of Phosphorus in Drained Grassland Soils. J. Environ. Qual. 27: 515-522.

Steingruber, S. M., 2001. Nutrient transformations in a wetland pond. Ph. D. Thesis. No. 13939. Eidgenössische Technische Hochschule (ETH), Zurich.

Tyrrell, T., 1999. The relative influences of nitrogen and phosphorus on oceanic primary production. Nature 400: 525-531.

Zimmermann, U., 1999. Die planktische Primärproduktion der trophischen Erholungsphase des Zürich- und des Walensees. Schweiz. Verein des Gas- und Wasserfaches 1: 29-33.

Zobrist, J., H. Bührer and J. S. Davis, 1990. Zeitliche Entwicklung des Stickstoffs in den Schweizerischen Gewässern. Mitteilungen der EAWAG 30: 14-18.

\section{To access this journal online: \\ (20) http://www.birkhauser.ch}

